\title{
Perencanaan Pembangunan Pariwisata di Daerah (Studi Pelaksanaan Program pada Dinas Pemuda Olahraga dan Pariwisata Kabupaten Pekalongan)
}

\author{
Irwan Susanto $^{\text {a } *}$ \\ ${ }^{a}$ Dinas Pemuda, Olah Raga dan Pariwisata Kabupaten Pekalongan, Jawa Tengah, Indonesia
}

INFORMASI ARTIKEL

Article history:

Dikirim tanggal: 29 Agustus 2016

Revisi pertama tanggal: 25 Oktober 2016

Diterima tanggal: 01 November 2016

Tersedia online tanggal: 16 November 2016

Keywords: planning, tourism

development, attraction, marketing

\begin{abstract}
Tourism development in rural area implemented to eradicate poverty and the gap between rural and urban areas. The purpose of this study is to identify tourism development program that carried out in the rulal area from perspective of destination development, marketing and institutional development. Program destination development still dominated by the construction of infrastructure, in which lack attention to the construction of the attractions, the development of marketing is still stuck at an annual routine which has not based on modern marketing model, program of institutional development has been growing a tourism area in society however it is still not effective because of limited quality and quantity in human resources, accessibility, lack of facilities and infrastructure and also budget. The development model recommended is a community-based tourism development which pay more attention to community participation, environmental sustainability and social culture.
\end{abstract}

\section{INTISARI}

Pembangunan pariwisata didaerah bertujuan ikut serta dalam upaya mengentaskan kemiskinan dan kesenjangan antara desa dan kota. Tujuan penelitian ini adalah mengidentifikasi program pembangunan pariwisata yang dilaksanakan di daerah dilihat dari aspek pembangunan destinasi, pemasaran dan pembangunan kelembagaan. Program pengembangan destinasi masih didominasi pembangunan sarana dan prasarana, kurang memperhatikan pembangunan atraksi secara berkelanjutan, pembangunan pemasaran masih terjebak pada rutinitas tahunan belum mengacu pada model pemasaran modern, program pembangunan kelembagaan telah menumbuhkan lembaga-lembaga pariwisata di masyarakat namun belum efektif karena keterbatasan kualitas dan kuantitas sumber daya manusia, aksesibilitas, kurangnya sarana dan prasarana serta keterbatasan anggaran. Model pembangunan yang dianjurkan adalah pembangunan pariwisata berbasis komunitas yang lebih memperhatikan partisipasi masyarakat, keberlanjutan lingkungan dan sosial budaya.

2016 FIA UB. All rights reserved.

\section{Pendahuluan}

Bagian Indonesia memiliki pemandangan alam indah dan sangat mendukung berkembangnya sektor pariwisata. Pariwisata dianggap sebagai hal yang memiliki sifat multi dimensi dengan rangkaian dalam proses pembangunan. Pembangunan pariwisata berkaitan dengan masalah sosial, budaya, ekonomi dan politik (Hadinoto:1996).

* Corresponding author. Tel.: +62-812-7161-2016; e-mail: irwanspkl@gmail.com 
Pembangunan sektor pariwisata akan mendorong dan meningkatkan pertumbuhan ekonomi (Spillane, 1991). Kabupaten Pekalongan menetapkan salah satu tujuan pembangunan pariwisata adalah meningkatkan kesejahteraan masyarakat. namun di sisi lain, persentase penduduk miskin di Kabupaten Pekalongan masih cukup tinggi.

Tujuan penelitian ini adalah mendeskripsikan dan menganalisis tentang implementasi program pariwisata di Kabupaten Pekalongan serta partisipasi masyarakat dalam pelaksanaan program tersebut. Penelitian ini berkaitan dengan implementasi program pariwisata yang dilaksanakan pada Dinas Pemuda Olahraga dan Pariwisata Kabupaten Pekalongan dengan melihat dari aspek pembangunan destinasi pariwisata, aspek pemasaran pariwisata dan aspek pembangunan kelembagaan pariwisata.

Destinasi pariwisata menurut Cooper dalam Suwena (2010) harus didukung empat komponen utama atau yang dikenal dengan istilah " $4 \mathrm{~A}$ " yaitu atraksi (atttraction), fasilitas (amenities), aksesibilitas (acces), dan pelayananan tambahan (ancillary services). Perencanaan pemasaran pariwisata melibatkan beberapa kegiatan pokok, yaitu sebagai berikut:

a) Keyakinan dan ketersediaan sumber daya manusia untuk menjamin kesuksesan perencanaan pemasaran pariwisata;

b) Penentuan misi dan target perusahaan;

c) Audit internal dan eksternal,

d) Analisis situasi bisnis;

e) Penetapan tujuan pemasaran; dan

f) Penyediaan strategi bauran pemasaran yang efektif.

Bauran pemasaran terdiri dari produk, harga, promosi dan distribusi. Efektivitas perencanaan bauran pemasaran sangat tergantung pada kemampuan memilih target pasar, yang berarti juga kemampuan dalam mendiversifikasikan produk, sehingga mampu memuaskan konsumen dalam level yang tinggi. Faktor produk terdiri dari pelayanan, kualitas, jangkauan produk, merek, dan keunggulan. Faktor harga yakni bagaimana penentuan harga produk sehingga berkait dengan performance produk dan peluangnya dimasa depan.

Faktor promosi merupakan kegiatan komunikasi dimana organisasi berusaha mempengaruhi khalayak. Tahapan promosi dimulai dari penetapan tujuan promosi, menetapkan beberapa statemen alternatif, membuat solusi dalam bentuk serangkaian tujuan promosi yang terukur dan penilaian dari rencana promosi agar sesuai dengan anggaran yang tersedia, SDM, dan waktu yang diperlukan.

Menurut Etzioni (1982) beberapa unsur penting dari kelembagaan adalah "sebuah institusi sebagai dasar untuk mengembangkan tingkah laku sosial; norma yang telah menjadi urat nadi dalam sebuah kehidupan bermasyarakat serta diakui dalam meraih tujuan.; peraturan dan aturan yang ada di masyarakat. yang berisi hak dan kewajiban serta perilaku, kode etik, perjanjian, pengakuan hak milik.

Tingkat partisipasi masyarakat sangat penting dalam penyelenggaraan pariwisata berbasis komunitas. Tipologi bentuk partisipasi telah dicoba jelaskan oleh Arnstein (1969) dengan tangga partisipasinya. Tosun dalam Reid (2003) juga mengajukan tingkatan partisipasi dalam 3 hal pokok, yaitu coercive community participation, induced community participation dan spontaneus community participation.

\section{Teori}

\subsection{Perencanaan Pembangunan Pariwisata}

Dalam hal perencanaan pembangunan kawasan pariwisata, proses pengembangan dan pengkoordinasian tersebut menyangkut masa depan dari suatu destinasi pariwisata. Pada intinya, perencanaan pembangunan pariwisata membutuhkan perencanaan yang berbeda dengan perencanaan di sektor lain. Kebutuhan untuk perencanaan pariwisata yang terintegrasi dan terkoordinasi muncul untuk menyeimbangkan kebutuhan yang berbeda dalam sebuah daerah. Pembangunan rencana pariwisata yang terstruktur mengakui implikasi jangka panjang dari kegiatan pariwisata dan berupaya mengurangi dampak negatif yang ditimbulkan dan pada saat yang sama mencoba meningkatkan dampak yang menguntungkan. Penting bagi setiap daerah untuk membuat rencana yang lebih spesifik secara teratur dalam perencanaan pariwisata. Rencana tersebut akan memberikan fokus dan tindakan langsung pada kegiatan tertentu dan pengembangan program. Selanjutnya supaya lebih efektif, maka rencana tersebut diselaraskan dengan sistem perencanaan yang sedang berjalan. Seringkali rencana dilihat hanya menjadi sebuah dokumen tanpa diintegrasikan dengan tindakan secara teratur (Gunn, 1994:30).

Perencanaan pariwisata secara tradisi dilakukan oleh komunitas bisnis, pelaku bisnis pariwisata tertarik pada analisis pasar dengan menggunakan variabel yang dapat dimainkan sehingga mampu menghasilkan kesuksesan keuangan. Namun ada tipe selain pariwisata secara korporasi, yakni pembelajaran sosial dan pembangunan kapasitas masyarakat.

Inskeep mendefinisikan perencanaan sebagai mengorganisasikan masa depan untuk meraih tujuan tertentu (1991:26). Pendekatan yang komprehensif dan menyeluruh dibutuhkan bukan saja karena keseluruhan aspek (dalam perencanaan pariwisata) saling terkait, melainkan pula terhubung dengan lingkungan alamiah dan area sosial. Dengan segera, pemikiran Inskeep merubah kecenderungan para perencana pariwisata 
dalam memandang alam dan komunitas. Kedua hal itu kini dipandang sebagai subjek, bukan objek yang bisa dieksplorasi maupun dieksploitasi. Ide inilah yang kemudian diresapi oleh Inskeep dalam berbagai penjelasan selanjutnya terhadap cara serta proses bagaimana melakukan perencanaan pariwisata dalam lingkup nasional dan regional, serta dalam menganalisis perencanaan, memformulasikan kebijakan, mendesain pembangunan, mempertimbangkan dampak, maupun menstrategikan dan mengimplementasikan tourism plan.

Inskeep (1991) \& Gunn (1994), mengemukakan bahwa suatu kawasan wisata yang baik dan berhasil bila secara optimal didasarkan kepada empat aspek, yaitu:

a) Mempertahankan kelestarian lingkungannya;

b) Meningkatkan kesejahteraan masyarakat dikawasan tersebut;

c) Menjamin kepuasan pengunjung; dan

d) Meningkatkan keterpaduan dan unity pembangunan masyarakat disekitar kawasan dan zone pengembangannya.

Dengan demikian melalui konsep perencanaan pariwisata yang dijelaskan oleh Gunn dan Inskeep dapat ditarik kesimpulan bahwa dalam melakukan sebuah perencanaan suatu objek wisata, diperlukan adanya fokus yang lebih menyeluruh pada aspek lain selain sumber daya (atraksi) yang ada daerah sehingga pembangunan dan pengembangan objek pariwisata di suatu daerah selain untuk menggerakan roda ekonomi, diharapkan dapat berperan dalam menjaga kelestarian lingkungan hidup dan meningkatkan kesejahteraan masyarakat disekitarnya melalui keterlibatan secara langsung dalam sebuah pembangunan dan pengembangan pariwisata tersebut (Community Involvement).

\subsection{Pemasaran Pariwisata}

Pemasaran pariwisata menurut Cooper et all dalam Pitana (2009) digambarkan dalam gambar sebagai berikut:

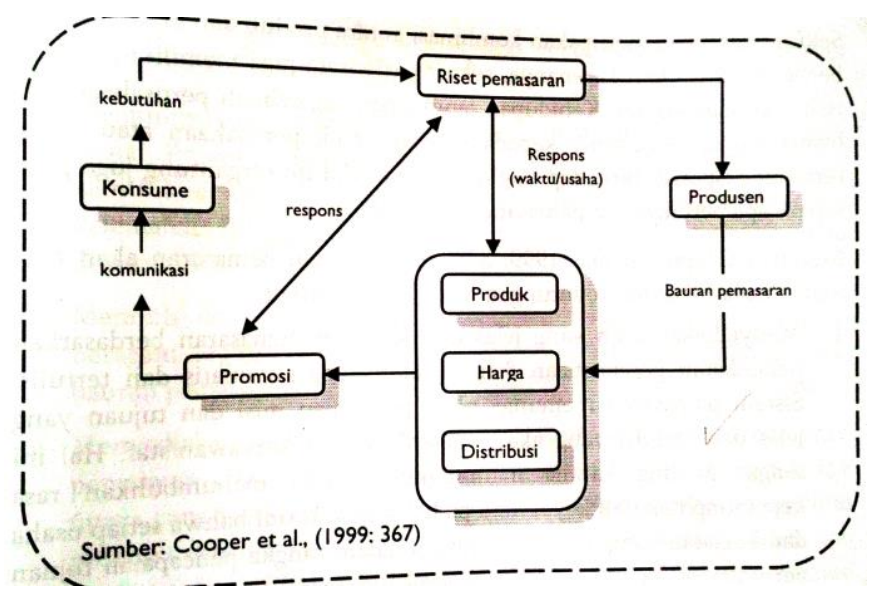

Gambar 1 Sistem Pemasaran Pariwisata
Menurut Pitana (2010:165) pemasaran pariwisata melibatkan beberapa karakteristik khusus, yaitu sebagai berikut:

a) Pemasaran merupakan filosofi yang didasari oleh sebuah nilai bahwa proses pengambilan keputusan oleh organisasi penyedia produk dan layanan harus didasari oleh kebutuhan konsumen, aset perusahaan dan sumber daya yang dimiliki;

b) Pemasaran yang sukses memerlukan struktur organisasi khusus yang mencerminkan orientasinya kepada konsumen; dan

c) Pemasaran memerlukan metode berpikir dan perencanaan inovatif sehingga ide-ide baru dapat diadopsi untuk meningkatkan metode pemasaran yang sudah ada.

Perencanan pemasaran pariwisata memegang peranan yang penting karena mewakili struktur dan arah kegiatan pemasaran tersebut. Menurut Pitana (2010:169) model perencanaan pemasaran pariwisata melibatkan beberapa kegiatan pokok, antara lain sebagai berikut:

a) Keyakinan dan ketersediaan sumber daya manusia untuk menjamin kesuksesan perencanaan pemasaran pariwisata;

b) Penentuan misi dan target perusahaan;

c) Audit internal dan eksternal;

d) Analisis situasi bisnis;

e) Penetapan tujuan pemasaran; dan

f) Penyediaan strategi bauran pemasaran yang efektif.

Bauran pemasaran terdiri dari produk, harga, promosi dan distribusi. Efektivitas perencanaan bauran pemasaran sangat tergantung pada kemampuan memilih target pasar, yang berarti juga kemampuan dalam mendiversifikasikan produk, sehingga mampu memuaskan konsumen dalam level yang tinggi. Faktor produk terdiri dari pelayanan, kualitas, jangkauan produk, merek, dan keunggulan. Faktor harga yakni bagaimana penentuan harga produk sehingga berkait dengan performance produk dan peluangnya di masa depan.

Faktor promosi merupakan kegiatan komunikasi dimana organisasi berusaha mempengaruhi khalayak. Tahapan promosi dimulai dari penetapan tujuan promosi, menetapkan beberapa statemen alternatif, membuat solusi dalam bentuk serangkaian tujuan promosi yang terukur dan penilaian dari rencana promosi agar sesuai dengan anggaran yang tersedia, SDM,dan waktu yang diperlukan. Dalam kegiatan promosi agar efektif yang perlu diperhatikan adalah efek komunikasi, advertising, promosi penjualan, marginalisasi, dan komodifikasi kebudayaan.

\subsection{Perencanaan Pembangunan Destinasi Pariwisata}

Pembangunan destinasi pariwisata atau daya tarik wisata menurut Suwena (2010:86) merupakan tempat dimana segala kegiatan pariwisata bisa dilakukan 
dengan tersedianya segala fasilitas dan atraksi wisata untuk wisatawan. Dalam mendukung keberadaannya perlu ada unsur pokok yang harus mendapat perhatian guna wisatawan dapat tenang, aman dan nyaman berkunjung. Suatu destinasi pariwisata Menurut Yoeti (1988:206) hendaknya memenuhi beberapa syarat yaitu ketersediaan sesuatu yang dapat dilihat, sesuatu yang dapat dilakukan, dan sesuatu yang dapat dibeli.

Destinasi pariwisata menurut Cooper dalam Suwena (2010) harus didukung empat komponen utama atau yang dikenal dengan istilah " $4 \mathrm{~A}$ " yaitu atraksi (attraction), fasilitas (amenities), aksesibilitas (acces), dan pelayananan tambahan (ancillary services). Keempat komponen utama tersebut dapat dijelaskan, yaitu sebagai berikut:

\section{a) Atraksi}

Atraksi merupakan alasan umum banyak orang untuk berkunjung ke suatu destinasi. Atraksi wisata ada tiga jenis, yakni alam, budaya dan buatan.

b) Amenity (fasilitas)

Fasilitas adalah segala macam prasarana dan sarana yang diperlukan oleh wisatawan selama berada di daerah tujuan wisata. Sarana tersebut seperti penginapan, usaha makanan minuman, transportasi, dan infrastruktur.

c) Aksesibilitas

Aksesibilitas merupakan jalan masuk utama ke suatu daerah tujuan wisata/ destinasi. Airport, pelabuhan, terminal dan berbagai macam sarana transportasi lain menjadi akses penting dalam pariwisata. Akses juga diidentikan dengan transferabilitas yaitu kemudahan untuk bergerak dari daerah satu ke daerah lain. Faktor-faktor yang memungkinkan transferabilitas adalah konektivitas antar daerah, tidak adanya penghalang, dan tersedianya sarana angkutan antar daerah.

d) Ancillary Services

Pelayanan tambahan atau pelengkap yang harus disediakan oleh pemerintah termasuk pembangunan fisik jalan raya, air minum, listrik, telepon, serta mengkoordinir segala macam aktivitas dan dengan peraturan perundang-undangan dan pemandu wisata.

\subsection{Pariwisata Berbasis Komunitas}

Pariwisata Berbasis Komunitas (Community Based Tourism) berkembang sejak pertengahan 1990an. Pariwisata berbasis komunitas secara umum dipahami sebagai dikelola dan dimiliki oleh komunitas untuk komunitas, berbentuk pariwisata lokal, penyediaan pelayanan setempat dan fokus pada interpretasi dan mengkomunikasikan budaya dan lingkungan setempat serta menjadi tujuan dan didukung oleh komunitas, pemerintah lokal dan LSM (Asker et all, 2010).

Menurut Garrod (2001:4), terdapat dua pendekatan berkaitan dengan penerapan prinsip-prinsip perencanaan dalam konteks pariwisata. Pendekatan pertama yang cenderung dikaitkan dengan sistem perencanaan formal sangat menekankan pada keuntungan potensial dari ekowisata. Pendekatan kedua, cenderung dikaitkan dengan istilah perencanaan yang partisipatif yang lebih peduli dengan ketentuan dan pengaturan yang lebih seimbang antara pembangunan dan perencanaan terkendali. Pendekatan ini lebih menekankan pada kepekaan terhadap lingkungan alam dalam dampak pembangunan wisata.

Suansri (2003:14) mendefinisikan pariwisata berbasis komunitas sebagai pariwisata yang memperhitungkan aspek keberlanjutan lingkungan, sosial dan budaya. Pariwisata berbasis komunitas merupakan alat pembangunan komunitas dan konservasi lingkungan, atau dengan kata lain pariwisata berbasis komunitas merupakan alat untuk mewujudkan pembangunan pariwisata yang berkelanjutan.

Ciri-ciri khusus dari Community Based Tourism menurut Hudson (Timothy, 1999:373) adalah berkaitan dengan manfaat yang diperoleh dan adanya upaya perencanaan pendampingan yang membela masyarakat lokal serta lain kelompok memiliki ketertarikan/ minat, yang memberi kontrol lebih besar dalam proses sosial untuk mewujudkan kesejahteraan. Yaman \& Mohd (2004:584-587) menggarisbawahi beberapa kunci implementasi pembangunan pariwisata dengan pendekatan pariwisata berbasis komunitas, yaitu sebagai berikut:

a) Adanya dukungan pemerintah: pariwisata berbasis komunitas membutuhkan dukungan struktur yang multi institusional agar sukses dan berkelanjutan. Pendekatan pariwisata berbasis komunitas berorientasi pada manusia yang mendukung pembagian keuntungan dan manfaat yang adil serta mendukung pengentasan kemiskinan dengan mendorong pemerintah dan masyarakat untuk tetap menjaga SDA dan budaya. Pemerintah akan berfungsi sebagai fasilitator, koordinator atau badan penasehat SDM dan penguatan kelembagaan.

b) Partisipasi dari stakeholder pariwisata berbasis komunitas didiskripsikan sebagai variasi aktivitas yang meningkatkan dukungan yang lebih luas terhadap pembangunan ekonomi dan sosial masyarakat. Pariwisata berperan dalam pembangunan internal dan mendorong pembangunan aktivitas ekonomi yang lain seperti industri, jasa dan sebagainya.

c) Ketiga, pembagian keuntungan yang adil. Tidak hanya berkaitan dengan keuntungan langsung yang diterima masyarakat yang memiliki usaha di sektor pariwisata tetapi juga keuntungan tidak langsung yang dapat dinikmati masyarakat yang tidak memilki usaha.

d) Keempat, penggunaan sumber daya lokal secara berkesinambungan. Salah satu kekuatan ekowisata 
adalah ketergantungan yang besar pada sumber daya alam dan budaya setempat. Dimana aset tersebut dimiliki dan dikelola oleh seluruh anggota masyarakat, baik secara individu maupun kelompok, termasuk yang tidak memiliki sumber daya keuangan.

e) Kelima, penguatan institusi lokal. Pada awalnya peluang usaha pariwisata di daerah pedesaan sulit diatur oleh lembaga yang ada. Penting untuk melibatkan komite dengan anggota berasal dari masyarakat. Tujuan utamanya adalah mengatur hubungan antara penduduk, sumber daya dan pengunjung.

f) Keenam, keterkaitan antara level regional dan nasional. Komunitas lokal seringkali kurang mendapat link langsung dengan pasar nasional atau internasional, hal ini menjadi penyebab utama mengapa manfaat pariwisata tidak sampai dinikmati dilevel masyarakat.

Perencanaan berbasis komunitas dapat menjadi sarana dan katalis untuk pengembangan masyarakat. Dan momentum pengembangan masyarakat, dimana pemangku kepentingan menjadi terbiasa untuk bekerja sama, dapat membantu perencanaan berbasis komunitas sehingga kebutuhan fasilitasi dari pihak netral berkurang. Perencana/ peneliti/ fasilitator kemudian dapat pindah sebagai salah satu dari beberapa sumber daya untuk proses perencanaan dan pembangunan berkelanjutan dengan membantu pelatihan, pendidikan, dan inisiatif pembangunan kapasitas lokal.

\section{Metode Penelitian}

Penelitian ini menggunakan metode kualitatif untuk menemukan jawaban atas permasalahan yang telah diajukan. Penelitian kualitatif digunakan karena menggambarkan jenis penelitian yang mampu mempelajari makna kehidupan manusia dalam dunia nyata, merepresentasikan pandangan dan perspektif yang diteliti bukan dari sudut pandang peneliti, mencakup keseluruhan kondisi kontekstual yang berada dalam situs penelitian, memberikan wawasan (insights) dalam menjelaskan fenomena yang ada sehingga menjadi sebuah konsep tertentu, dan penelitian kualitatif menggunakan berbagai sumber sehingga tercapai kredibilitas yang dapat dipercaya dan diandalkan (Yin, 2011). Dalam meneliti proses perencanaan yang dilaksanakan di Kabupaten Pekalongan, maka dilakukan dengan analisis deskriptif dengan analisis data dengan model Yin (2011). Yin mengemukakan metode analisis data dengan melalui lima tahapan, antara lain (1) Compiling, (2) disassembling, (3) reassembling (and Arraying), (4) Interpreting, and (5) Concluding.

\section{Hasil Penelitian dan Pembahasan}

\subsection{Aspek Pembangunan Destinasi Pariwisata di Kabupaten Pekalongan}

Dalam upaya membangun pengelolaan destinasi kawasan diperlukan untuk menjadi acuan dalam pengembangan sebuah destinasi. Kawasan tersebut telah diatur dalam rencana tata ruang wilayah Kabupaten Pekalongan. Menurut Inskeep (1991) daya tarik terbagi menjadi tiga, yakni wisata alam, wisata budaya, dan wisata buatan.

Pariwisata disuatu tempat pada dasarnya karena tempat tersebut memiliki daya tarik yang mampu mendorong wisatawan untuk datang berkunjung. Murray dalam Gunn (2002) menyebutkan bahwa sesuatu atau gambaran yang menggambarkan orang untuk tertarik sesuai hasrat, selera dan sebagainya khususnya pertunjukan yang luar biasa atau menarik dengan dipenuhi banyak orang.

Di Kabupaten Pekalongan, kegiatan yang dilaksanakan sebagian bersifat fisik struktur dan infrastruktur yang dibutuhkan di objek wisata. Pada dasarnya terdiri dari kegiatan pembangunan, pemeliharaan dan rehabilitasi di destinasi wisata. Infrastruktur yang telah cukup diperhatikan adalah infrastruktur jalan, karena bupati terpilih dalam janji kampanyenya mengatakan bahwa infratruktur yang akan dibangun adalah jalan. Hal tersebut mengingat infrastruktur jalan menjadi prioritas utama. Di Kabupaten Pekalongan, kawasan pariwisata telah terhubung namun belum ada sarana transportasi yang memadai. Maka perlu diupayakan sarana transportasi masal yang memungkinkan, ataupun dengan menggunakan upaya penyediaan sarana transportasi khusus yang diusahakan oleh penduduk setempat misalnya ojek, mobil sewaan sehingga wisatawan dapat lebih leluasa berkunjung. Untuk menuju ke kawasan Petungkriyono tidak bisa diakses dengan bus besar karena jalan yang curam dan sempit. Aksesibilitas adalah salah satu unsur dari infrastruktur penting dalam pembangunan destinasi sebagaimana dikemukakan oleh Bovy dan Lawson (1998) “... should be posible by public transport and bicycle traills, by pedestrian paths (from neighbourhoods) and by cars (mainly families, with an average of three person/car)...". Aksesibilitas yang bersifat fisik maupun non fisik menuju objek wisata merupakan hal penting dalam pembangunan pariwisata. Aspek fisik antara lain jalan, kelengkapan fasilitas, jumlah dan frekwensi transportasi umum dan terminal. Menurut Bovy dan Lawson (1998) dikatakan bahwa "jaringan jalan memiliki dua peran penting dalam kegiatan pariwisata yaitu sebagai alat akses, transport, komunikasi antara pengunjung dengan atraksi rekreasi atau fasilitas dan sebagai cara untuk melihat-lihat (sightseeing) dan menemukan suatu tempat yang 
membutuhkan perencanaan dalam penentuan pemandangan yang dapat dilihat selama perjalanan."

Peran aksesibilitas yang kedua menunjukan bahwa aspek non fisik merupakan faktor penting dalam mendukung aksesibilitas secara keseluruhan, yakni keamanan, waktu tempuh. Dalam memahami aksesibilitas maka Bovy dan Lawson (1998) menyatakan bahwa jalan dibagi menjadi dua kategori, yaitu jalan utama dan jalan pengunjung sebagai jalan sekunder.

Dalam pembangunan destinasi dibutuhkan fasilitas yang berfungsi sebagai pelengkap dan guna memenuhi kebutuhan wisatawan. Menurut Bukart dan Medlik (1974), "fasilitas bukanlah merupakan faktor utama yang dapat menstimulasi kedatangan wisatawan ke suatu destinasi, tetapi ketiadaan fasilitas dapat menghalangi wisatawan dalam menikmati atraksi wisata. Jadi fasilitas haruslah bersifat melayani dan mempermudah kegiatan atau aktifitas pengunjung/ wisatawan yang dilakukan dalam rangka mendapat pengalaman rekreasi. Namun fasilitas dapat menjadi daya tarik wisata apabila penyajianya disertai dengan keramahtamahan yang menyenangkan wisatawan". Menurut Bovi dan Lawson (1998) "fasilitas adalah atraksi buatan manusia yang berbeda dari daya tarik wisata yang lebih cenderung berupa sumber daya."

Pembangunan destinasi tidak dapat dilepaskan dari aspek keindahan. Karena pembangunan fasilitas yang sebenarnya bukan merupakan atraksi dapat menjadi atraksi penunjang apabila dapat dikemas secara inovatif dan menarik, misalnya sarana MCK sebagai sarana penunjang, namun apabila dikemas dengan bentuk bangunan misalnya berbentuk binatang atau bangunan unik lainya akan menjadi daya tarik tersendiri. Gazebo yang merupakan sarana pendukung namun apabila dikemas dalam bentuk goa mini dengan model menarik akan menjadi atraksi yang dapat menarik minat pengunjung. Dan hal tersebut belum ditemui pada destinasi wisata yang ada di Kabupaten Pekalongan. Belum ada konsep yang jelas terhadap pembangunan yang dilakukan. Pendekatan kegiatan masih merupakan pendekatan fisik semata belum menyentuh nilai estetika dan filosofi tertentu.

Persoalan aksesibilitas yang sulit sebenarnya dapat diolah menjadi atraksi yang menarik, misalnya aksesibilitas yang sulit dari Malang ke Gunung Bromo dapat dimanfaatkan secara baik oleh masyarakat menjadi sumber pendapatan dengan menciptakan atraksi tersendiri dengan kendaraan jeep yang menjadi keharusan bagi pengunjung yang ingin berkunjung kesana. Pengelola Ekowisata Petungkriyono sudah mencoba meniru hal tersebut dengan menawarkan paket jemputan menggunakan jeep dari pasar Doro menuju ke Petungkriyono dan sekitarnya serta sekaligus paket wisata ekowisata yang menarik.

\subsection{Aspek Pemasaran Pariwisata di Kabupaten Pekalongan}

Dalam upaya pemasaran pariwisata Kabupaten Pekalongan sebagaimana hasil penelitian menetapkan target pada wisatawan domestik, sedangkan wisatawan mancanegara belum menjadi prioritas. Pameran yang diikuti telah mentarget pasar secara berjenjang dari tingkat lokal sampai pasar nasional. Walaupun demikian, promosi yang dilakukan belum dllakukan secara kreatif, baru berdasarkan kegiatan tahun-tahun sebelumnya, baik secara lokasi maupun konten dari promosi dan pemasaran tersebut.

Pemerintah baru sebatas memamerkan potensi yang ada dan belum ada tindak lanjut ataupun monitoring mengenai efektivitas pameran tersebut terhadap kontribusinya pada peningkatan jumlah wisatawan. Padahal menurut Yoeti (2005) usaha pemasaran harus berkelanjutan dan karena itu hendaknya merupakan suatu proses manajemen yang tiada henti-hentinya. Proses manajemen dalam artian bahwa suatu proses harus berkelanjutan, menerapkan strategi dan teknik pemasaran modern terutama dalam hal perencanaan penelitian, peramalan, seleksi pasar atau saluran distribusi. Media promosi yang dilakukan Dinas Pemuda Olahraga dan Pariwisata Kabupaten Pekalongan baru sebatas pameran, pembuatan leaflet, pembuatan event tertentu, namun belum menggunakan teknik promosi modern misalnya dengan memanfaatkan jejaring media sosial, iklan di televisi, videotron, sponsorship pada klub terkenal, pemberian diskon, hadiah atau perangsang lain.

Pemasaran dalam kepariwisataan menurut Yoeti (2005) merupakan suatu hal yang kompleks karena produk dari pariwisata memiliki ciri-ciri khas dibandingkan produk berupa barang dan lagi pula produk pariwisata sering berkaitan dengan beberapa perusahaan, instansi dan lembaga masyarakat. Disatu pihak harus ada kerjasama dan di pihak lain tidak jarang terjadi pula sebaliknya.

Kabupaten Pekalongan perlu menetapkan branding pariwisata sebagai merek sebagaimana pendapat Pitana (2010) bahwa faktor produk dalam bauran pemasaran pariwisata terdiri dari pelayanan, kualitas, jangkauan produk, merek, dan keunggulan. Merek menjadi nilai lebih dalam perencanaan pemasaran karena akan menjadi pendongkrak atau nilai tambah yang akan menghubungkan antara pikiran konsumen dengan produk kita. Dengan penetapan branding yang baik, maka akan membentuk citra daerah yang baik.

Kabupaten Pekalongan pada Tahun 2014 mencoba hal tersebut dengan mempopulerkan slogan "dadi kajen”, yakni slogan untuk mencoba menjadikan perpindahan pusat pemerintahan ke Kota Kajen dilakukan sebagai upaya untuk menjadikan Kabupaten Pekalongan benar-benar 'Kajen' atau arti makna kata 
Jawa sebenarnya yakni terhormat. Tiga filosofi itu, pertama untuk mewujudkan eksistensi sebuah kota kabupaten yang mandiri memiliki harga diri dan mempunyai jati diri sebuah kabupaten. Kedua, mengembangkan kota Kabupaten Pekalongan dan ketiga, mendekatkan pelayanan kepada masyarakat. Sebab pemerintah dalam melakukan pelayanan semestinya mendekat ke rakyat. Bukan sebaliknya, rakyat yang mendekat ke pemerintah.

Apabila dilihat dari proses perencanaan pembuatan program pemasaran di Dinas Pemuda Olahraga dan Pariwisata Kabupaten Pekalongan, belum melaksanakan sesuai dengan pendapat Pitana (2010) bahwa dalam membuat program pemasaran dilakukan dengan keyakinan dan ketersediaan sumber daya manusia untuk menjamin kesuksesan perencanaan pemasaran pariwisata; penentuan misi dan target perusahaan; audit internal dan eksternal; analisis situasi bisnis; penetapan tujuan pemasaran; dan penyediaan strategi bauran pemasaran yang efektif.

Pembuatan program masih terbelenggu pada pagu anggaran dan hanya melanjutkan ataupun copy paste dari anggaran tahun sebelumnya. Belum ada upaya untuk melakukan analisa mengenai kebutuhan pemasaran yang harus dilakukan. Upaya survey konsumen belum dilakukan, penelusuran efektivitas promosi dan pemasaran yang telah dilakukan juga belum dibuat. Sehingga program pemasaran yang dilakukan sebagian besar tidak mencapai target pasar sesuai kebutuhan.

Pemanfaatan media sosial belum dilakukan dengan adanya fakta bahwa Dinas Pemuda olahraga dan pariwisata belum memiliki akun media sosial ataupun aplikasi populer lainya yang akan dapat menjangkau audien secara lebih spesifik dan masif. Pemanfaatan media sosial akan dengan cepat menghubungkan antara penyedia produk dengan konsumen sehingga setiap informasi dapat dengan cepat dan efektif tersampaikan. Bahkan penyedia dapat berinteraksi secara intens dengan konsumen mengenai kelebihan dan kekurangan, harapan-harapan pengunjung wisata, apalagi jika sudah dibuatkan aplikasi online berbasis teknologi informasi mengenai hal tersebut.

Dinas Pemuda olahraga dan pariwisata telah merilis website Dinas sebagai upaya meng-upgrade kualitas pelayanan dengan situs

dinporapar.pekalongankab.go.id. Namun sejak dirilis sejak bulan Agustus 2015 belum ada update mengenai konten website tersebut. Hal ini membuktikan bahwa belum ada mindset yang benar terhadap strategi pemasaran pariwisata yang harus dilakukan. Pendekatan anggaran masih dipertahankan, padahal ada cara murah dengan hasil yang lebih efektif untuk menjangkau dan mempromosikan Kabupaten Pekalongan.
Apabila ditelusuri dibeberapa objek wisata tertentu sudah menyadari mengenai efektivitas pemasaran melalui media sosial tersebut, antara lain di destinasi Curugbajing telah memiliki akun facebook sebagai aplikasi paling populer di Kabupaten Pekalongan serta akun instagram untuk memamerkan hal-hal dan informasi terbaru mengenai destinasi yang ada. Bahkan pengelola sudah menjalin kerjasama dengan beberapa stasiun televisi nasional untuk menayangkan destinasi Curugbajing ditingkat nasional. Promosi melalui acara televisi sangat menguntungkan karena tidak perlu mengeluarkan dana sedikitpun namun efek dari penayangan destinasi tersebut sangat efektif dalam menjangkau dan menarik minat pengunjung.

\subsection{Aspek Kelembagaan Pariwisata di Kabupaten Pekalongan}

Masalah dari aspek kelembagaan di Kabupaten Pekalongan adalah bahwa Pokdarwis belum berjalan. Pokdarwis seharusnya mengkoordinasikan kegiatan wisata desa dan bisa diarahkan menjadi pengelola. Masih belum ada aktivitas nyata dari Pokdarwis, sehingga pengelolaan wisata masih sangat terbatas. Masalah manajerial adalah manajemen yang masih sangat tradisional dan terfragmentasi, tidak terintegrasi dan antarpelaku usaha seperti pengrajin, kuliner, jasa wisata, dan kesenian belum ada sinergisitas dan kesamaan sikap dan langkah dalam mengembangkan wisata. Di Desa Lolong belum nampak lembaga yang dapat mengatur kegiatan wisata desa secara sinergis.

Persoalan kapasitas adalah masih kurangnya kapasitas masyarakat dan lembaga-lembaga yang ada dalam meningkatkan pengetahuan dan kemampuan pengelolaan wisata yang baik dan berdaya saing. Lemahnya transfer pengetahuan dan penguasaan teknologi serta pengelolaan wisata membuat potensi potensi wisata yang ada tidak dapat dimanfaatkan secara optimal. Persoalan sosial adalah adanya ego antar warga ditempat wisata terhadap warga lainnya, sehingga tidak terjadi kerja sama dan sinergi pengelolaan wisata. Disisi lain juga terdapat perasaan tidak percaya diantara warga karena kurangnya transparansi pengelolaan. Ada jarak diantara warga terutama desa dan warga dusun lainnya. Persoalan yang sekarang dihadapi adalah rendahnya kohesi sosial, masing-masing pihak sibuk dengan urusan usahanya sendiri tanpa memperhatikan usaha yang saling terkait. Masyarakat kurang memahami bahwa dengan melakukan kerja bersama mereka akan mendapat manfaat bersama. Kendala sosial pariwisata adalah belum siapnya masyarakat dalam menghadapi kunjungan wisata.

Reid (2003) mengemukakan bahwa model perencanaan pengembangan masyarakat pariwisata menawarkan kerangka perencanaan pariwisata makro dan penting untuk memberi penekanan mengenai 
penilaian masyarakat dan tahap pengembangan organisasi. Secara kelembagaan, komunitas yang paling diharapkan berperan dalam pengembangan pariwisata berbasis komunitas adalah kelompok sadar wisata. Berdasarkan Peraturan Menbudpar Nomor PM.04/UM.001/MKP/2008 tentang sadar wisata, kelompok sadar wisata tidak hanya sekedar mengenai kesadaran masyarakat sebagai pendukung pariwisata, namun lebih jauh lagi diharapkan masyarakat ikut berpartisipasi sehingga dapat terwujud nilai manfaat ekonomi yang sebesar-besarnya bagi kesejahteraan masyarakat. Pentingnya kelompok sadar wisata tersebut dapat dilihat dari tindak lanjut yang dilakukan Gubernur Jawa Tengah dengan surat edaran nomor 556/01515 Tahun 2010 mengenai pembentukan kelompok sadar wisata. Tujuan dari kelompok sadar wisata tersebut adalah meningkatkan kadar pemahaman masyarakat tentang peranan pariwisata dalam pembangunan nasional, sehingga secara sadar dan bertanggung jawab berperan serta dalam mencapai sasaran pembangunan pariwisata nasional

Berdasarkan pemaparan diawal tampak bahwa implementasi program pariwisata di Kabupaten Pekalongan telah dilaksanakan dengan menciptakan pengembangan pariwisata yang secara konseptual memiliki ciri-ciri unik serta sejumlah karakter. Apabila dikaitkan dengan pendapat Suansri (2003) dalam gagasannya bahwa ada delapan poin dalam pariwisata berbasis komunitas. Pembangunan pariwisata di Kabupaten Pekalongan telah mengakui, mendukung dan mengembangkan kepemilikan komunitas dalam industri pariwisata. Pemerintah daerah mengembangkan komunitas dalam bentuk kelompok sadar wisata yang dipercaya mampu melakukan perencanaan dan pengelolaan wisata setempat. Pemerintah telah berusaha mengikutsertakan anggota komunitas dalam memulai setiap aspek kegiatanya, walaupun dalam kenyataanya seringkali diwakili oleh elit dalam komunitas.

Distribusi keuntungan secara adil menjadi poin penting mengingat komunitas pariwisata sebagian besar mendasarkan pada pendekatan ekonomi, sehingga kegiatan komunitas merupakan kegiatan ekonomi yang berusaha mendatangkan keuntungan finansial. Hal tersebut juga ditegaskan oleh Yaman \& Mohd (2004) bahwa pembagian keuntungan yang adil berkaitan dengan keuntungan tak langsung yang diterima masyarakat walaupun tidak berkaitan secara langsung.

Dibeberapa destinasi yang ada di Kabupaten Pekalongan, pembagian keuntungan yang adil seringkali masih menjadi kendala, dimana pengelolaan keuntungan yang dihasilkan dan dibagikan oleh pengurus komunitas masih banyak menjadi perdebatan diantara anggota komunitas, bahkan ada pihak lain yang mempertanyakan hal tersebut. Di Curugbajing, pembagian keuntungan telah diatur dalam bentuk peraturan desa yang telah menetapkan besaran sharing antara anggota komunitas dan pihak lain yang terkait. Namun di beberapa destinasi lainya masih belum tampak peraturan yang menjadi kesepakatan bersama di antara stakeholder yang terkait.

Bentuk pengelolaan pariwisata yang sebagian besar dimiliki oleh masyarakat dan hubungannya dengan peran pemerintah secara terpadu sesuai arahan perencanaan kedepan dapat digambarkan, yaitu sebagai berikut:

Gambar 2 Model Pengembangan Pembangunan Pariwisata di Kabupaten Pekalongan

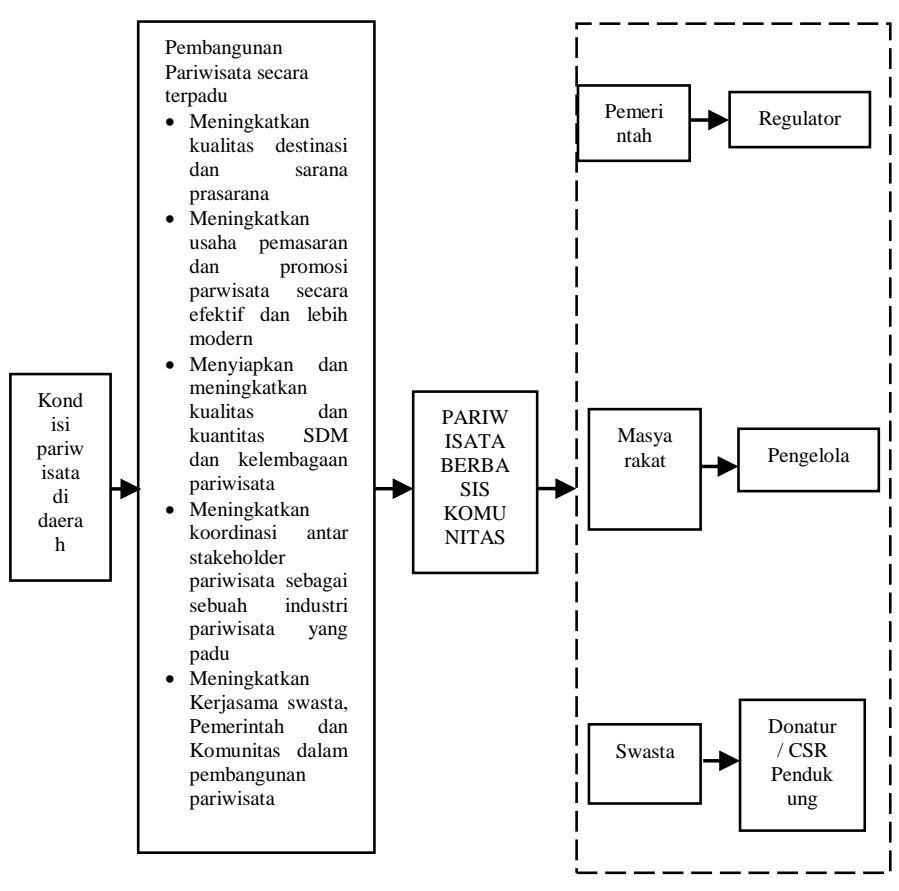

Menurut teori Butler (1980) mengenai Tourism Area Life Cycle of Evolution, ada siklus destinasi yang ada disuatu tempat. Kawasan dan objek wisata di Kabupaten Pekalongan berdasarkan ciri-ciri yang dijelaskan dimuka berada ditahapan involvement/ pelibatan. Dimana dalam tahap ini jumlah pengunjung/ wisatawan mulai meningkat, Peran pemerintah dan masyarakat setempat mulai terlibat.

Yang perlu diperhatikan adalah bagaimana membentuk kesadaran masyarakat, bahwa destinasi wisata mereka merupakan aset berharga sehingga senantiasa dijaga dan dilestarikan serta tidak dijual kepada pemodal besar. Karena menurut Butler pada tahap ketiga yakni tahap pembangunan akan datang pemerintah dan swasta dalam skala besar yang dapat mengancam eksistensi masyarakat sekitar. Memang pada saat sekarang hal tersebut baru dalam tataran investasi kecil, namun apabila pengelola berhasil mengembangkan destinasi ke tahap selanjutnya, maka dengan sendirinya investasi akan mengalir ke daerah tersebut. 


\section{Kesimpulan}

Berdasarkan hasil penelitian dan pembahasan dapat diambil beberapa kesimpulan, yaitu sebagai berikut:

a) Perencanaan telah didukung dokumen perencanaan yang cukup baik, namun masih perlu perencanaan yang lebih komprehensif dan lengkap sehingga arahan pembangunan pariwisata dapat lebih efektif dan efisien. Implementasi program pariwisata di Kabupaten Pekalongan dari segi pembangunan destinasi pariwisata di Kabupaten Pekalongan ditujukan pada kawasan destinasi utama yakni Linggosri dan Petungkriyono dengan melengkapi sarana dan prasarana, aksesibilitas, dan fasilitas bagi wisatawan. Namun dari segi kualitas masih belum mencukupi dan masih banyak kekurangan yang harus ditingkatkan; dan

b) Aspek Pemasaran pariwisata dalam pelaksanaan program masih dilakukan melalui pameran, penyelenggaraan event dan pembuatan leaflet serta belum memanfaatkan teknik pemasaran yang lebih modern. Aspek kelembagaan dalam pelaksanaan program dilaksanakan dengan melakukan pembentukan kelompok sadar wisata di kawasan destinasi wisata utama guna menunjang akselerasi pembangunan pariwisata daerah. Selain itu juga telah diupayakan pembinaan melalui pelatihan, dan studi banding. Tingkat partisipasi masyarakat dalam perencanaan pariwisata masih belum memuaskan, tingkatan partisipasi masih dalam tingkatan partisipasi semu.

\section{Daftar Pustaka}

Arnstein, Sherry R. (1969). A Ladder of Citizen Participation. JAIP, 35 (4), pp. 216-224.

Asker, Sally. et all. (2010). Asia-Pasific Economic Cooperation: Effective Community Based Tourism: A Best Practice Manual. Sydney: Sustainable Tourism Cooperative Research Center.

Bovy, M.Baud and Lawson, Fred R. (1998). Tourism and Recreation Handbook of Planning and Design. Oxford: Architectural Press.

Burkart, A.J. and Medlik, S. (1974). Tourism: Past, Present and Future. London: Heinemann.

Butler, R.W. (1980). The Concept of a Tourism Area Cycle of Evolution: Implications for Management Resources. The Canadian Geographer, 24(1), pp. 5-16.

Etzioni, Amitai. (1982). Organisasi-Organisasi Modern, Terjemahan Suryatim. Jakarta: UI Press.

Garrod, Brian. (2001). Local Partisipation in the Planning and Management of Ecotourism: A Revised Model Approach. Bristol: University of the West of England.
Gunn, C. \& T, Var. (1994). Tourism Planning, Basics, Concepts, Cases. Routledge, New York.

Gunn, C. \& T, Var. (2002). Tourism Planning: Basics, Concepts, Cases, $4^{\text {th }}$ Edition. Routledge, New York.

Hadinoto, Kusudianto. (1996). Perencanaan Pengembangan Destinasi Pariwisata. UI Press, Jakarta.

Inskeep, E. (1991). Tourism Planning: An Integrated and Sustainable Development Approach. Van Nostrand Reinhold, New York.

Peraturan Menteri Kebudayaan dan Pariwisata Nomor PM.04/UM.001/MKP/2008 tentang Sadar Wisata.

Pitana, I Gede. \& Surya Diarta, I Ketut. (2009). Pengantar Ilmu Pariwisata. Yogyakarta: ANDI.

Pitana, I Gede. \& Surya Diarta, I Ketut. (2010). Pengantar Ilmu Pariwisata. Yogyakarta: ANDI.

Reid, Donald G. (2003). Tourism, Globalization and Development: Responsible Tourism Planning. Pluto Press, London.

Spillane, J.J. (1991). Ekonomi Pariwisata: Sejarah dan Prospeknya. Yogyakarta: Kanisius.

Suansri, Potjana. (2003). Community Based Tourism Handbook. REST PROJECT, Thailand.

Suwena, I Ketut. (2010). Pengetahuan Dasar Ilmu Pariwisata. Denpasar: Udayana Press.

Timothy, D.J. (1999). Participatory Planning a View of Tourism in Indonesia. Annals of Tourism Research, Vol. 26, Issue 2, pp. 251-492.

Yaman, A.R. \& Mohd. (2004). Community Based Ecotourism: New Proposition for Sustainable Development and Environment Conservation in Malaysia. Journal of Applied Sciences, IV(4), pp. $583-589$.

Yin, Robert K. (2011). Qualitatif Research From Start to Finish. The Guilford Press, New York.

Yoeti, Oka A. (1988). Pengantar Ilmu Pariwisata. Angkasa, Bandung.

Yoeti, Oka A. (2005). Perencanaan Strategi Pemasaran Daerah Tujuan Wisata. PT. Pradnya Paramit, Jakarta. 